\title{
POPULATION FLUCTUATIONS OF SOME APHID SPECIES INFESTING MAIZE PLANTS IN SHARKIA GOVERNORATE
}

\author{
SHERIEF, E.A.H. ${ }^{2}$, F. A. EL-LAKWAH ${ }^{1}$, A. A. DARWISH ${ }^{1}$ and \\ EMAN M. EL-GOHARY2
}

1. Plant protection Dept., Fac. of Agric., Moshtohor, Benha univ., Egypt.

2. Plant Protection Research Institute, ARC, Dokki, Giza.

(Manuscript received 17 July 2011)

\begin{abstract}
The results showed that three aphid species namely Rhopalosiphum maidis, R. padi and Aphis gossypii infesting maize plants in Sharkia governorate. $R$. maidis was the most abundant species on maize plants during 2008 and 2009 seasons. The highest population densities occurred in $3^{\text {rd }}$ week of August for all districts i.e., Zagazig, Belbeis, Abou-Hammad and Meniet El-Kamh whereas their values were 1279.80, 955.45, 544.32 and 1095.06 aphids/plant, respectively during the first season. But during 2009 it appeared with higher population (1399.99, 820.79, 506.06 and 598.79 aphids/plant). On the other hand $R$. padi reached its peak during $3^{\text {rd }}$ week of August with $(423.83,640.63,395.78$ and 234.76 aphids/plant) for season 2008 and during 2009 it appeared with (297.32, 640.63, 395.78 and 276.66 aphids/plant) for Zagazig, Belbeis, Abou-Hammad and Meniet El-Kamh, respectively. In addition $A$. gossypii indicated its peak on $4^{\text {th }}$ week of August with values of $343.36,372.03,378.56$ and 457.30 aphids/plant, respectively for the same previous districts at the first season and (338.03 \&395.36 aphids/plant) for Zagazig and abou-Hammad at $1^{\text {st }}$ week of September and (418.73 \&357.96 aphids/plant) for Belbies and Meniet El-Kamh for the second season. During the last week of September, the population density of different aphid's species was obviously reduced on maize plants in various districts under study. We can use these results in IPM program for controlling aphids on Maize.
\end{abstract}

Key words: $R$. maidis, R. padi, A. gossypii, population density.

\section{INTRODUCTION}

Crops of family gramineae are considered of great economic importance for local consumption. Maize (Zea Mays L.) is the stable food for the majority of Egyptian farmer's .Maize foliage and grains are also a major constituent in cattle feeds, due to its economic importance. The area cultivated annually with corn reached about 2.1 million Feddan .This areas is cultivated in multiple plantations throughout a long period extending from March to October in order to be used as fodder plant or for seed production. There are some pests species playing an important role which infested different crops such as Maize, Wheat and Sorghum.On maize (Rhopalosiphum maidis, R. padi and Aphis gossypii) are the major pests infesting maize crop. Ganguli 
and Ray Chaudry (1985) and El-Heneidy et. al., 2004. reported that $R$. maidis caused severe damage to maize and other plants, it was observed at Wheat, Barley and Sorghum fields and causes a considerable loss to the quantity and quality of the maize grain yield, moreover under favorite conditions the insect produces several generations and can causes heavy damage in scab and reduced vigor, stunting, yellowing of leaves and delayed tillering and grain formation. Excretion of honey dew by the insect encourages sooty mold. So the aim of this work was to study the effect of temperature, relative humidity and population dynamic of aphid species infesting maize plants.

\section{MATERIALS AND METHODS}

To study the population dynamics of aphids infesting maize plants in Sharkia Governorate, an area of about $1 / 2$ Feddan of maize plants was planted in four districts i.e. Zagazig, Abou- Hammad, Meniet El- kamh and Belbies at Sharkia governorate to evaluate the population fluctuations of different aphid species i.e. $R$. maidis, $R$. padi and $A$. gossypii during two successive seasons of 2008 and 2009. Sampling started when the infestation with maize aphid appeared, which containing 15 plants. Weekly samples were taken randomly from every replicate. The infested tassel and leaves were placed in paper bags and transferred to the laboratory for examination. The numbers of individuals of each stage alatae forms, apterous and nymphs were separately counted using a hand lens. A simple apparatus was used for this purpose, which was consisted of a wooden desk, a white card board paper divided into $4 \mathrm{~cm}$ apart columns put in the bottom, on which glass plate was placed and the upper surface of the glass plate was allowed to be wet with fine droplets of water to reduce the movement of counted aphids (Hegab, 1987). The leaves were carefully shaken off on to the plate and the aphid insects were counted using a small brush in each column.

\section{Statistical analysis:}

The correlation between population densities of aphid species, $R$. maidis $\mathrm{F} ., R$. padi L., and A. gossypii G., and some weather factors (maximum, minimum temperature and relative humidity) were statistically analyzed according to Snedecor and Cochran (1982).

\section{RESULTS AND DISCUSSION}

In the present work the following three species were surveyed. These aphid species harbourd on maize:

1. Rhopalosiphum maidis (Fitch). 
2. Rhopalosiphum padi (Linnaeus).

3. Aphis gossypii (Glover).

The results revealed that plant samples proved to be efficient method for collecting aphids during the two successive seasons of investigation (2008 and 2009). These results agreed with those of Hegab, 1987 who mentioned that plant sample is an efficient method for collecting aphids. But Hegab-ola, 2001 who mentioned that sticky trap method is one of the best sampling methods available for estimating winged aphids population on maize fields. Three aphid species were occurred on maize plants. R. maidis (F.) was the most abundant specie on maize plants during 2008 and 2009 seasons.

\section{A) Rhopalosiphum maidis (F.):}

The mean numbers of aphid collected from maize plants during 2008 and 2009 seasons at 4 districts namely Zagazig, Abou-Hammad, Belbeis and Meniet El-Kamh at Sharkia Governorate are shown in Table (1) and illustrated graphically in Fig (1). According to the obtained results it could be mentioned that the aphids were found under the field conditions of maize during the period from $2^{\text {nd }}$ week of July to $2^{\text {nd }}$ week of September. The mean numbers of initial occurrence were 22.53 and 47 aphids / plant sample on Zagazig district, Belbeis 18.80 and 82.06, Abou-Hammad it showed 11.96 and 31.53 and appeared with 14.86 and 50.32 at Meniet El-Kamh, at mean temperature of $27.90^{\circ} \mathrm{C}$ and $30.08{ }^{\circ} \mathrm{C}$ and $59.80 \%$ and $55.27 \%$ R.H., respectively for 2008 and 2009. The results showed that the highest population density of $R$. maidis individuals occurred in the third week of August with a mean number of (1279.80, 955.45, 544.32 and 1095.06) for Zagazig, Belbeis, AbouHammad and meniet El-Kamh, respectively in season 2008 at $29.02{ }^{\circ} \mathrm{C}$ and 62.67 R.H.\% . On the other hand in season 2009 aphid appeared on $3^{\text {rd }}$ week of July in both districts Zagazig and Belbeis but in Abou-Hammad and Meniet El-Kamh it appeared on $2^{\text {nd }}$ week of July with highest population of $R$. maidis individuals occurred with mean number of $(1399.99,820.79,506.06$ and 598.79) for Zagazig, Belbeis, Abou-Hammad and meniet El-Kamh respectively during 2009 season at a mean temperature $30.97 \circ \mathrm{C}$ and $66.27 \%$ R.H. After this peak the aphid numbers tended to decline until reached its minimal number in the $2^{\text {nd }}$ week of September with a mean number of $(72.89$, 43.42, 40.16 and 48.73 aphids / plant) in season 2008 and 211.62, 77.69, 84.92 and 109.86 aphids / plant during 2009 for Zagazig, Belbeis, Abou-Hammad and meniet ElKamh respectively at $33.47^{\circ} \mathrm{C}$ and $37.19^{\circ} \mathrm{C}$ and $58.29 \%$ and $60.13 \%$ R.H for 2008 and 2009 season, respectively. These results are in agreement with those reported by many authors estimated population fluctuation of $R$. maidis on maize plants Farag et. al., (1992) in Egypt observed one peak representing $R$. maidis (F.) occurred also at 
the third week of August. Amal (2008) surveyed some homopterous insects infesting certain graminaeous field crop also the seasonal abundance of the dominant species $R$. maidis attacking maize plants and caused high damage showed only one peak on 3rd week of August. The statistical analysis of correlation Table (2) cleared that there were highly significant positive correlation between $R$. maidis population infesting maize in Zagazig ,Belbeis ,Abou-Hammad and Meniet El-Kamh and minimum relative humidity during first season where $r=0.922^{* *}, 0.794^{* *}, 0.878^{* *}$ and $0.902^{* *}$ for districts mentioned above, respectively. The correlation was insignificant with temperature and maximum relative humidity during the first season in all districts. The statistical analysis of correlation cleared that there were highly significant positive correlation between $R$. maidis population infesting in Zagazig and Abou-Hammad and minimum relative humidity during the second season where $r=0.928^{* *}$ and $0.913^{* *}$, respectively. Also there was a significant positive correlation between $R$. maidis population and the minimum relative humidity during the second season in Meniet ElKamh where $r=0.852^{*}$. The correlation was insignificant for temperature and maximum relative humidity in the second season. 
Table 1. Mean number of aphid Rhopalosiphum maidis (F.) Infesting maize plants collected by plant samples at 4 districts, Sharkia Governorate during 2008 and 2009 seasons.

\begin{tabular}{|c|c|c|c|c|c|c|c|c|c|c|c|c|c|}
\hline \multirow{3}{*}{\multicolumn{2}{|c|}{$\begin{array}{l}\text { Date of } \\
\text { inspection } \\
\text { (weekly) }\end{array}$}} & \multicolumn{8}{|c|}{ Mean number of aphid/plant sample } & \multicolumn{4}{|c|}{ Mean of } \\
\hline & & \multicolumn{2}{|c|}{ Zagazig } & \multicolumn{2}{|c|}{ Belbeis } & \multicolumn{2}{|c|}{ Abou-Hammad } & \multicolumn{2}{|c|}{ Meniet El-Kamh } & \multicolumn{2}{|c|}{ Temp. ${ }^{\circ} \mathrm{C}$} & \multicolumn{2}{|c|}{ R.H.\% } \\
\hline & & 2008 & 2009 & 2008 & 2009 & 2008 & 2009 & 2008 & 2009 & 2008 & 2009 & 2008 & 2009 \\
\hline \multirow{5}{*}{ July } & $1^{\text {st }}$ & 0 & 0 & 0 & 0 & 0 & 0 & 0 & 0 & 28.18 & 29.10 & 59.87 & 58.47 \\
\hline & $2^{\text {nd }}$ & 22.53 & 0 & 18.80 & 0 & 11.96 & 31.53 & 14.86 & 50.32 & 27.90 & 30.08 & 59.80 & 55.27 \\
\hline & $3^{\text {rd }}$ & 63.12 & 47 & 48.13 & 82.06 & 39.42 & 46.99 & 44.96 & 68.39 & 30.95 & 30.27 & 56.60 & 65.40 \\
\hline & $4^{\text {th }}$ & 151.53 & 141.99 & 123.72 & 169.69 & 111.72 & 109.06 & 114.29 & 135.59 & 31.16 & 30.71 & 67.27 & 65.15 \\
\hline & $5^{\text {th }}$ & 320.62 & 408.19 & 219.03 & 286.79 & 137.22 & 145.39 & 241.75 & 242.46 & 30.06 & 32.68 & 66.87 & 64.60 \\
\hline \multirow{4}{*}{ Aug. } & $1^{\text {st }}$ & 378.09 & 512.69 & 262.23 & 528.56 & 235.19 & 239.06 & 303.75 & 373.79 & 30.07 & 30.65 & 70.40 & 68.33 \\
\hline & $2^{\text {nd }}$ & 555.09 & 824.79 & 337.42 & 604.13 & 374.15 & 407.26 & 512.30 & 530.72 & 32.60 & 32.05 & 63.50 & 70.60 \\
\hline & $3^{\text {rd }}$ & 1279.80 & 1399.99 & 955.45 & 820.79 & 544.32 & 506.06 & 1095.06 & 598.79 & 29.02 & 30.97 & 62.67 & 66.27 \\
\hline & $4^{\text {th }}$ & 1170.39 & 918.32 & 271.66 & 504.53 & 191.29 & 337.93 & 479.19 & 372.53 & 29.70 & 29.10 & 58.14 & 64.87 \\
\hline \multirow{3}{*}{ Sep. } & $1^{\text {st }}$ & 212.26 & 320.56 & 115.35 & 204.02 & 98.35 & 144.18 & 187.83 & 270.39 & 36.26 & 39.35 & 56 & 56.29 \\
\hline & $2^{\text {nd }}$ & 72.89 & 211.62 & 43.42 & 77.69 & 40.16 & 84.92 & 48.73 & 109.86 & 33.47 & 37.19 & 58.29 & 60.13 \\
\hline & $3^{\text {rd }}$ & 0 & 0 & 0 & 0 & 0 & 0 & 0 & 0 & 36.49 & 39.10 & 58.57 & 57 \\
\hline \multicolumn{2}{|c|}{ Total } & 4226.52 & 4985.15 & 2395.21 & 3228.26 & 1783.78 & 2052.38 & 3042.72 & 3382.84 & & & & \\
\hline
\end{tabular}


Table 2. Correlation coefficients between temperature, relative humidity and population densities of Rhopalosiphum maidis F. on maize in four districts during the period of 2008- 2009.

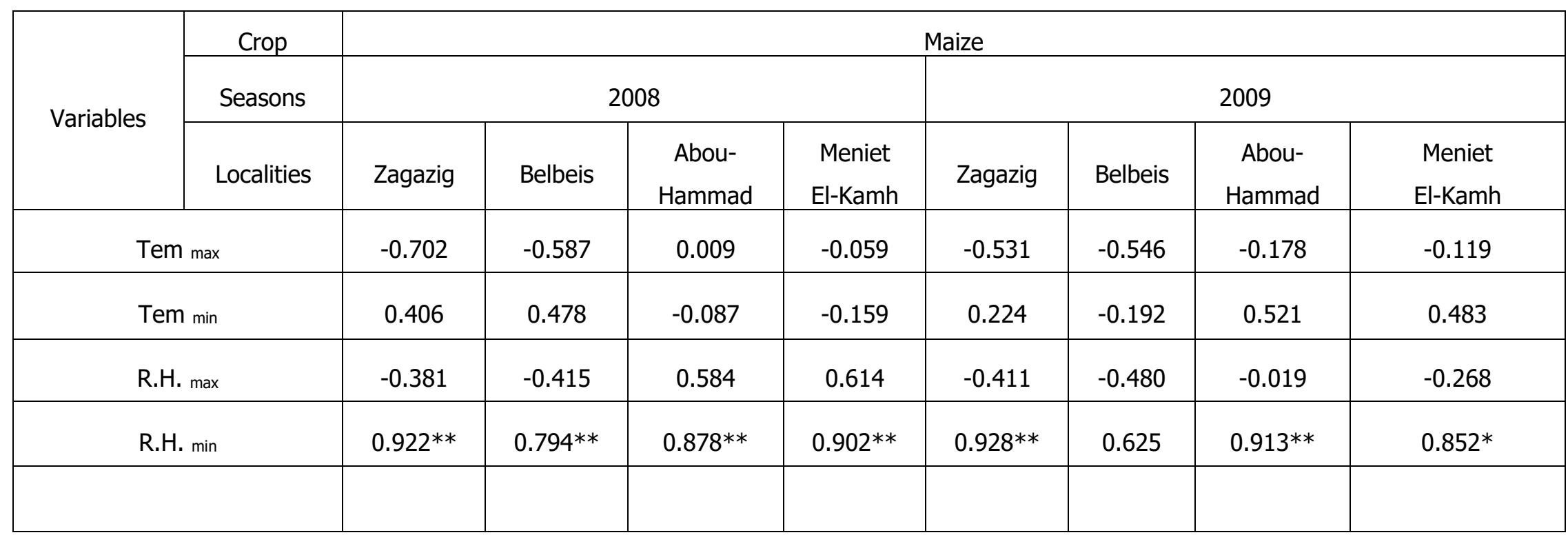




\section{8}

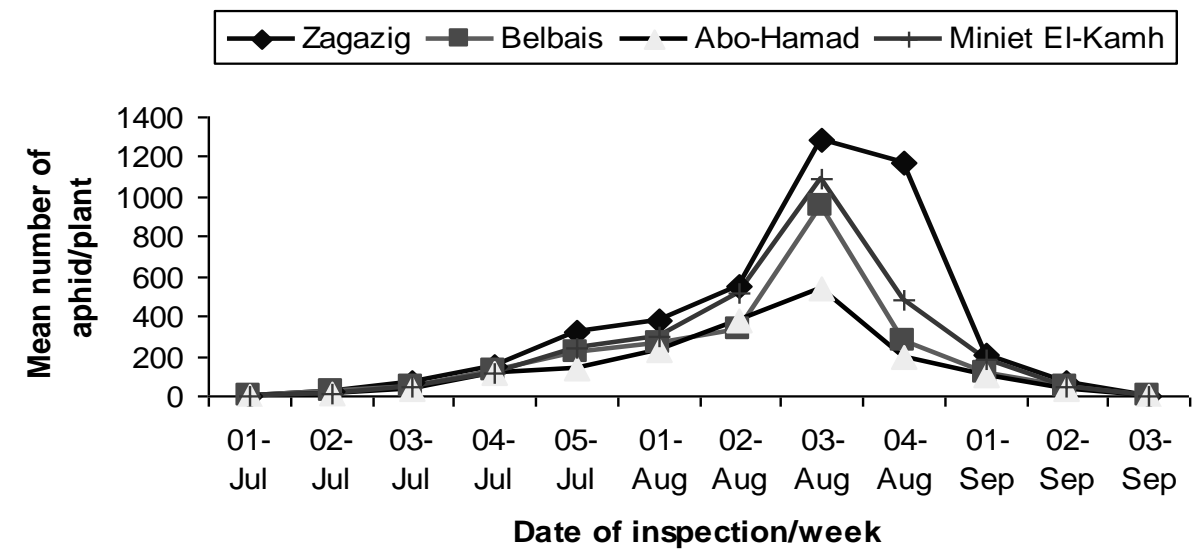

$\rightarrow$ Temperature $2008 \multimap$ Temperature $2009 \_-\mathrm{R} . \mathrm{H} \% 2008 \multimap \mathrm{R} . \mathrm{H} \% 2009$

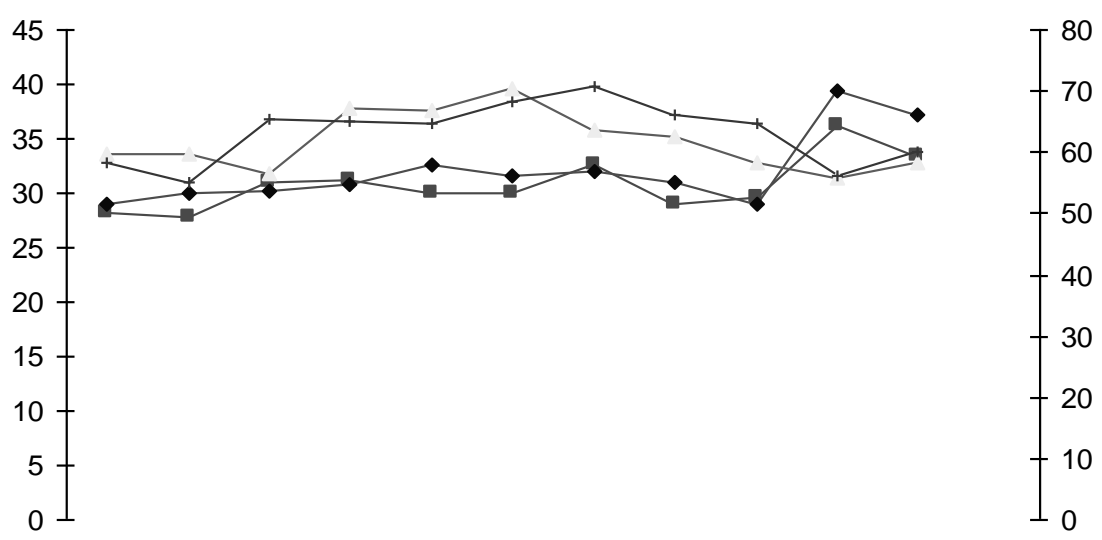

2009

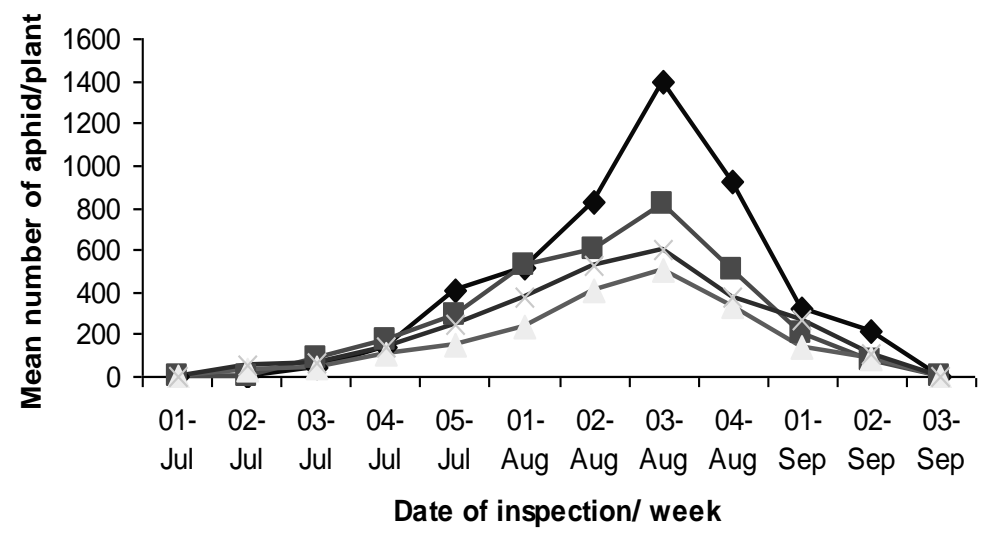

Fig 1. Population fluctuation of Rhopalosiphum maidis (F.) infesting maize plants collected by plant samples at 4 districts, Sharkia Governorate during 2008 and 2009 season, respectively. 


\section{B) Rhopalosiphum padi (L.):}

Samples of 15 plants were picked up weekly from maize plants during the period from third week of July to the second half of September for two experimental seasons. The mean number of aphid $R$. padi infesting maize plants are given in Table (3) and illustrated graphically in Fig (2). The first sample of $R$. padi was collected at third week of July on maize plants. The mean numbers of initial appearance were 118.43, 81.76, 93.93 and 43.09 aphids / plant for Zagazig, Belbeis, Abou-Hammad and meniet El-Kamh respectively at $30.95 \circ \mathrm{C}$ and $56.60 \%$ R.H. in the first season and (90.46, 94.70 and 52.96) for Belbeis, Abou-Hammad and meniet El-Kamh at $30.71 \% \mathrm{C}$ and $65.15 \%$ R.H. and appeared in Zagazig with mean number 85.39 at $32.68 \% \mathrm{C}$ and $64.60 \%$ R.H. in the second season during $4^{\text {th }}$ week of July. Fig (2) illustrated cleared one peak of activity of $R$. padi on maize plants occurred in third week of August with a mean number of (423.83, 640.63, 395.78 and 234.76 aphids / plant) for Zagazig, Belbeis, Abou-Hammad and meniet El-Kamh respectively at 29.02 C at $62.67 \%$ R.H in the first season and showed also one peak in the second season on $4^{\text {th }}$ week of August (427.32, 568.66 and 276.66 aphids / plant) for Belbeis, Abou-Hammad and meniet El-Kamh, respectively, at $29.10{ }^{\circ} \mathrm{C}$ at $64.87 \%$ R.H., while at Zagazig 400.23 on $1^{\text {st }}$ Sep. at $39.35 \% \mathrm{C}$ at $56.29 \%$ R.H. After this peak the aphid numbers tended to decline until reached its minimal number in September with a mean number of (28.02, 46.26, 38.66 and 29.59 aphids / plant) in 2008 season at $33.47{ }^{\circ} \mathrm{C}$ and $58.29 \%$ R.H, (54.39, 59.03 and 53.42) during 2009 for Belbeis, AbouHammad and meniet El-Kamh respectively at $39.10{ }^{\circ} \mathrm{C}$ and $57 \%$ R.H for 2009 in Zagazig district it was $56.20 \%$ R.H. These results are in agreement with finding of Mohamed (1996) in Egypt who mentioned that, R. padi (L.) was represented by one peak at the end of March on wheat and barley and also one on maize at the beginning of October. The statistical analysis of correlation (Table 4) cleared that there were insignificant negative correlation between $R$. padi population infesting maize in Belbeis and meniet El-Kamh with maximum temperature. It was positive with minimum temperature during the first seasons, while there were insignificant negative correlation with minimum temperature during the second season in Abou-Hammad and Meniet El-Kamh $r=-0.142$ and -0.289 , respectively. While it was insignificant with maximum relative humidity during second season in Zagazig and Belbeis districts. Also, there were highly significant correlation between population and temperature in Zagazig

district. 
Table 2.Correlation between temperature, relative humidity and population densities of Rhopalosiphum padi L. on maize in four districts during the period of 2008- 09:

\begin{tabular}{|c|c|c|c|c|c|c|c|c|c|}
\hline \multirow{3}{*}{ Variables } & \multirow{3}{*}{$\begin{array}{c}\text { Crop } \\
\text { Seasons } \\
\text { Localities }\end{array}$} & \multicolumn{8}{|c|}{ Maize } \\
\hline & & \multicolumn{4}{|c|}{2008} & \multicolumn{4}{|c|}{2009} \\
\hline & & Zagazig & Belbeis & $\begin{array}{c}\text { Abou- } \\
\text { Hammad }\end{array}$ & $\begin{array}{c}\text { Meniet El- } \\
\text { Kamh }\end{array}$ & Zagazig & Belbeis & $\begin{array}{c}\text { Abou- } \\
\text { Hammad }\end{array}$ & $\begin{array}{c}\text { Meniet El- } \\
\text { Kamh }\end{array}$ \\
\hline \multicolumn{2}{|c|}{ Tem max } & $0.821^{* *}$ & -0.592 & $0.788^{*}$ & -0.514 & $0.911^{* *}$ & $0.911^{* *}$ & -0.064 & -0.186 \\
\hline \multicolumn{2}{|c|}{ Tem min } & $0.744^{*}$ & 0.477 & $0.737^{*}$ & 0.505 & $0.885^{* *}$ & $0.881^{* *}$ & -0.142 & -0.289 \\
\hline \multicolumn{2}{|c|}{ R.H. max } & $0.928 * *$ & $-0.755^{*}$ & $0.894^{* *}$ & -0.482 & -0.627 & -0.650 & 0.576 & 0.597 \\
\hline \multicolumn{2}{|c|}{ R.H. min } & $-0.786^{*}$ & $0.875^{* *}$ & $-0.740^{*}$ & $0.952 * *$ & $-0.743^{*}$ & $-0.721^{*}$ & $0.966^{* *}$ & $0.930 * *$ \\
\hline
\end{tabular}


Table 3. Mean number of aphid Rhopalosiphum padi (L.) infesting maize plants collected by plant samples at 4 districts, Sharkia Governorate during 2008 and 2009 seasons.

\begin{tabular}{|c|c|c|c|c|c|c|c|c|c|c|c|c|c|}
\hline \multirow{3}{*}{\multicolumn{2}{|c|}{$\begin{array}{c}\text { Date of } \\
\text { inspection } \\
\text { (weekly) }\end{array}$}} & \multicolumn{8}{|c|}{ Mean number of aphid/plant sample } & \multicolumn{4}{|c|}{ Men of } \\
\hline & & \multicolumn{2}{|c|}{ Zagazig } & \multicolumn{2}{|c|}{ Belbeis } & \multicolumn{2}{|c|}{ Abou-Hammad } & \multicolumn{2}{|c|}{ Meniet El-Kamh } & \multicolumn{2}{|c|}{ Temp. ${ }^{\circ} \mathrm{C}$} & \multicolumn{2}{|r|}{ R.H.\% } \\
\hline & & 2008 & 2009 & 2008 & 2009 & 2008 & 2009 & 2008 & 2009 & 2008 & 2009 & 2008 & 2009 \\
\hline \multirow{5}{*}{ July } & $1^{\text {st }}$ & 0 & 0 & 0 & 0 & 0 & 0 & 0 & 0 & 28.18 & 29.10 & 59.87 & 58.47 \\
\hline & $2^{\text {nd }}$ & 0 & 0 & 0 & 0 & 0 & 0 & 0 & 0 & 27.90 & 30.08 & 59.80 & 55.27 \\
\hline & $3^{\text {rd }}$ & 118.43 & 0 & 81.76 & 0 & 93.93 & 0 & 43.09 & 0 & 30.95 & 30.27 & 56.60 & 65.40 \\
\hline & $4^{\text {th }}$ & 173.40 & 0 & 129.20 & 90.46 & 124.43 & 94.70 & 98.19 & 52.96 & 31.16 & 30.71 & 67.27 & 65.15 \\
\hline & $5^{\text {th }}$ & 202.16 & 85.39 & 171.60 & 132.89 & 136.56 & 124.33 & 106.96 & 97.89 & 30.06 & 32.68 & 66.87 & 64.60 \\
\hline \multirow{4}{*}{ Aug. } & $1^{\text {st }}$ & 237.13 & 170.43 & 187.53 & 187.33 & 154.60 & 161.03 & 121.06 & 131.32 & 30.07 & 30.65 & 70.40 & 68.33 \\
\hline & $2^{\text {nd }}$ & 362.56 & 232.86 & 365.70 & 204.29 & 236.36 & 219.66 & 191.72 & 161.36 & 32.60 & 32.05 & 63.50 & 70.60 \\
\hline & $3^{\text {rd }}$ & 423.83 & 268.90 & 640.63 & 310.56 & 395.78 & 460.03 & 234.76 & 205.66 & 29.02 & 30.97 & 62.67 & 66.27 \\
\hline & $4^{\text {th }}$ & 139.79 & 297.32 & 261.02 & 427.32 & 176.93 & 568.66 & 115.26 & 276.66 & 29.70 & 29.10 & 58.14 & 64.87 \\
\hline \multirow{4}{*}{ Sep. } & $1^{\text {st }}$ & 63.50 & 400.23 & 99.46 & 135.99 & 56.79 & 275.33 & 68.76 & 230.55 & 36.26 & 39.35 & 56 & 56.29 \\
\hline & $2^{\text {nd }}$ & 28.02 & 234.03 & 46.26 & 54.39 & 38.66 & 104.76 & 29.59 & 97.36 & 33.47 & 37.19 & 58.29 & 60.13 \\
\hline & $3^{\text {rd }}$ & 0 & 81.76 & 0 & 0 & 0 & 59.03 & 0 & 53.42 & 36.49 & 39.10 & 58.57 & 57 \\
\hline & $4^{\text {th }}$ & 0 & 49.36 & 0 & 0 & 0 & 0 & 0 & 0 & 34.06 & 37.23 & 57 & 56.20 \\
\hline \multicolumn{2}{|c|}{ Total } & 1678.82 & 1896.28 & 1983.16 & 2130.67 & 1414.04 & 2067.53 & 1009.39 & 1363.95 & & & & \\
\hline
\end{tabular}




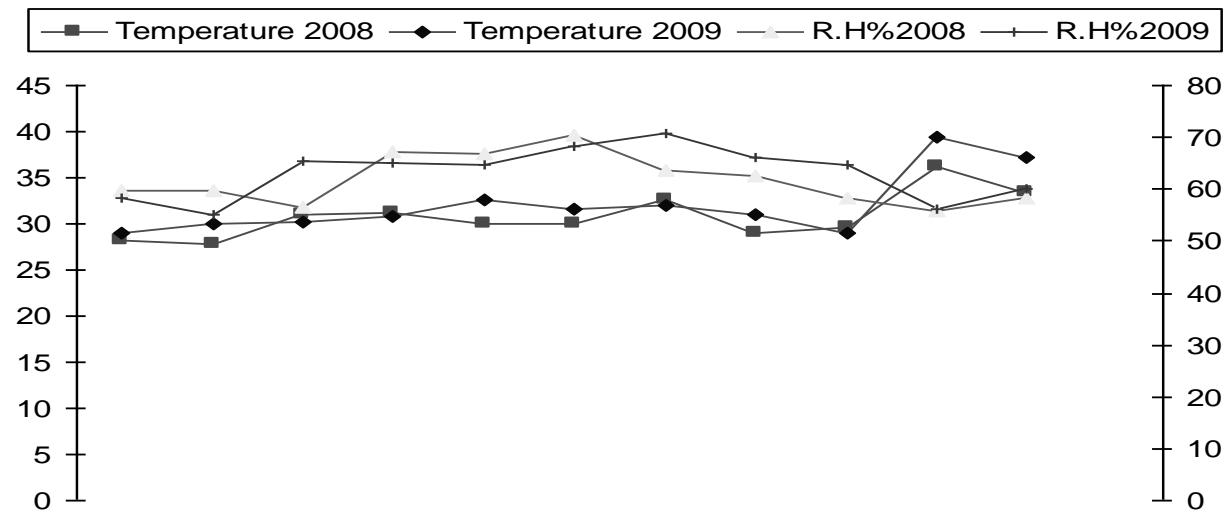

2008

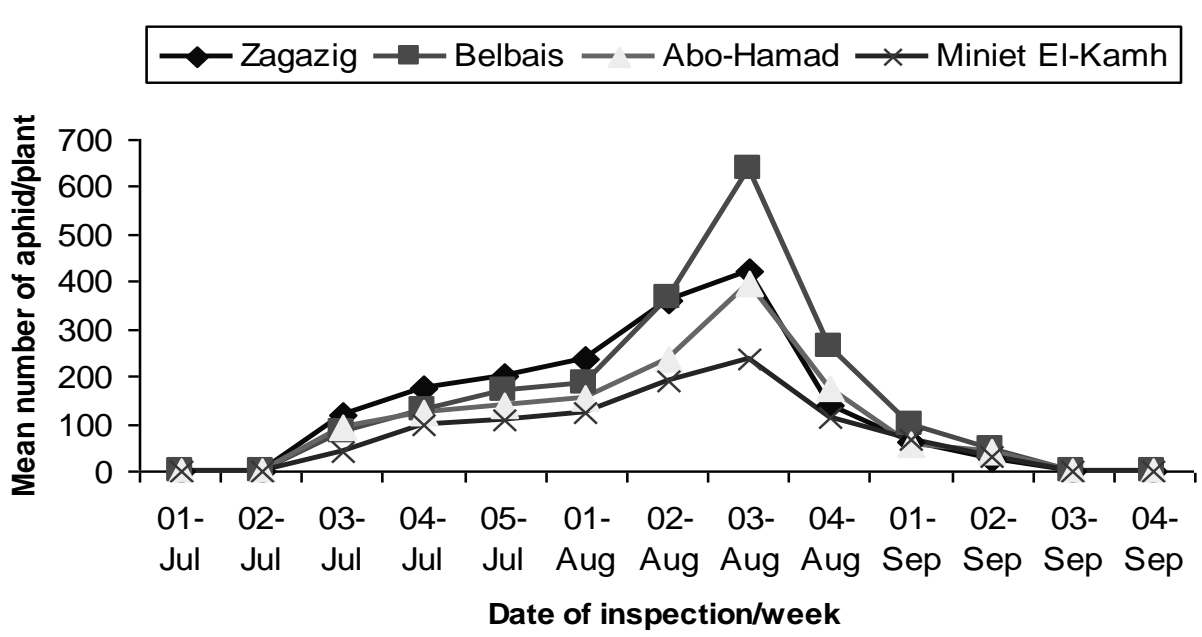

2009

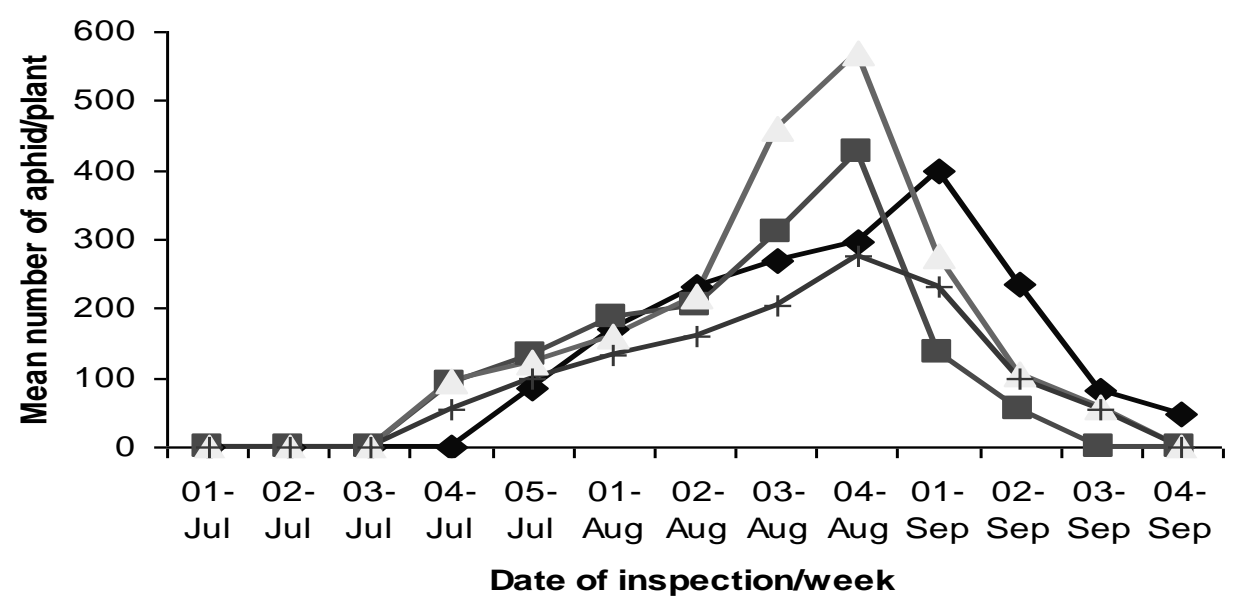

Fig 2. Population fluctuation of Rhopalosiphum padi (L.) infesting maize plants collected by plant samples at 4 districts, Sharkia Governorate during 2008 and 2009 season, respectively. 
C) Aphis gossypii (G.):

The mean numbers of aphid collected from maize plants during 2008 and 2009 seasons at 4 districts i.e., Zagazig, Belbeis, Abou-Hammad, and Meniet El-Kamh at Sharkia Governorate are shown in Table 5 and illustrated graphically in Fig (3). According to the obtained results it could be mentioned that the aphids were found in field of maize during the period from $4^{\text {th }}$ week of July to $2^{\text {nd }}$ week of September (2008 and 2009 season). The mean numbers of initial occurrence were 43.40 and 46.03 aphids / plant sample in Zagazig and 84.03 \&79.36 in Meniet El-Kamh at mean temperature of $31.16^{\circ} \mathrm{C}$ and $30.71{ }^{\circ} \mathrm{C}$ and $67.27 \%$ and $65.15 \%$ R.H, respectively for 2008 and 2009 and Belbeis at 63.03 and Abou -Hammad at 69.90 at $31.16^{\circ} \mathrm{C}$ and $67.27 \%$ in first season and 60.03 and 68.83 at $32.68{ }^{\circ} \mathrm{C}$ and $64.60 \%$ R.H. in $2^{\text {nd }}$ season. The results showed that the highest population density of $A$. gossypii individuals occurred in the $4^{\text {th }}$ week of August with a mean numbers of $343.36,372.03$, 400.56 and 457.30 for Zagazig ,Belbeis, Abou-Hammad and meniet El-Kamh, respectively in season 2008 at $29.700^{\circ} \mathrm{C}$ and 58.14 R.H.\% . On $4^{\text {th }}$ week of August 2009, the highest population of $A$. gossypii individuals was recorded with mean numbers of 352.06, 418.73 and 357.96 for Zagazig, Belbeis, and meniet El-Kamh, respectively at a mean temperature of $29.100^{\circ} \mathrm{C}$ and $64.87 \%$ R.H. For Abou-Hammad it appeared with 395.36 individual at $39.35^{\circ} \mathrm{C}$ and 56.29 R.H. \% at the beginning of September in season 2009. After this peak the aphid numbers tended to decline until reached its minimal number in September with a mean number of $(38.23,83.40$, 94.93 and 103.36) in 2008 season at $33.47^{\circ} \mathrm{C}$ and 58.29 R.H.\% and 41.53, 61.40, 89.66 and 42.70 in season 2009 at $39.10 \mathrm{c}$ and 57 R.H.\% .for Zagazig, Belbeis, AbouHammad and meniet El-Kamh respectively. Results in general concerning the populations of $R$. maidis, $R$. padi and $A$. gossypii in maize crops show clearly that these species have one peak on maize plants. These results are in agreement with findings of Abd-Alla (1985), Hegab (1987), Hegab-ola (2001) who showed that the flying activity of $R$. maidis, $R$. padi and $A$. gossypii have one peak on summer plantation. The statistical analysis of correlation Table 6 cleared that there were insignificant negative and positive correlation between $A$. gossypii population on maize at the four localities and temperature in $1^{\text {st }}$ season. It hesitated between negative and positive with maximum relative humidity. Also, there was significant positive correlation between the aphid population and the minimum relative humidity during the second season for two localities $(r=0.814)$ in Abou-Hammad and Meniet El-Kamh $(r=0.788)$. 
Table 5. Mean number of aphid Aphis gossypii (G.) Infesting maize plants collected by plant samples at 4 districts, Sharkia Governorate during 2008 and 2009 seasons.

\begin{tabular}{|c|c|c|c|c|c|c|c|c|c|c|c|c|c|}
\hline \multirow{3}{*}{\multicolumn{2}{|c|}{$\begin{array}{c}\text { Date of } \\
\text { inspection } \\
\text { (weekly) }\end{array}$}} & \multicolumn{8}{|c|}{ Mean number of aphid/plant sample } & \multicolumn{4}{|c|}{ Men of } \\
\hline & & \multicolumn{2}{|c|}{ Zagazig } & \multicolumn{2}{|c|}{ Belbeis } & \multicolumn{2}{|c|}{ Abou-Hammad } & \multicolumn{2}{|c|}{ Meniet El-Kamh } & \multicolumn{2}{|c|}{ Temp. ${ }^{\circ} \mathrm{C}$} & \multicolumn{2}{|c|}{ R.H.\% } \\
\hline & & 2008 & 2009 & 2008 & 2009 & 2008 & 2009 & 2008 & 2009 & 2008 & 2009 & 2008 & 2009 \\
\hline \multirow{5}{*}{ July } & $1^{\text {st }}$ & 0 & 0 & 0 & 0 & 0 & 0 & 0 & 0 & 28.18 & 29.10 & 59.87 & 58.47 \\
\hline & $2^{\text {nd }}$ & 0 & 0 & 0 & 0 & 0 & 0 & 0 & 0 & 27.90 & 30.08 & 59.80 & 55.27 \\
\hline & $3^{\text {rd }}$ & 0 & 0 & 0 & 0 & 0 & 0 & 0 & 0 & 30.95 & 30.27 & 56.60 & 65.40 \\
\hline & $4^{\text {th }}$ & 43.40 & 46.03 & 63.03 & 0 & 69.90 & 0 & 84.03 & 79.36 & 31.16 & 30.71 & 67.27 & 65.15 \\
\hline & $5^{\text {th }}$ & 71.53 & 84.10 & 94.56 & 60.03 & 107.53 & 68.83 & 102.63 & 91.8 & 30.06 & 32.68 & 66.87 & 64.60 \\
\hline \multirow{4}{*}{ Aug. } & $1^{\text {st }}$ & 143.30 & 159.93 & 188.76 & 97.16 & 225.10 & 96.70 & 243.36 & 134.53 & 30.07 & 30.65 & 70.40 & 68.33 \\
\hline & $2^{\text {nd }}$ & 213.86 & 227 & 209.20 & 208 & 255.23 & 221.40 & 310.76 & 256.46 & 32.60 & 32.05 & 63.50 & 70.60 \\
\hline & $3^{\text {rd }}$ & 249.16 & 254.03 & 282.96 & 303.36 & 292.93 & 293.10 & 333.26 & 314.13 & 29.02 & 30.97 & 62.67 & 66.27 \\
\hline & $4^{\text {th }}$ & 343.36 & 352.06 & 372.03 & 418.73 & 400.56 & 327.86 & 457.30 & 357.96 & 29.70 & 29.10 & 58.14 & 64.87 \\
\hline \multirow{4}{*}{ Sep. } & $1^{\text {st }}$ & 73.66 & 338.03 & 152.36 & 200.20 & 173.8 & 395.36 & 288.86 & 208.33 & 36.26 & 39.35 & 56 & 56.29 \\
\hline & $2^{\text {nd }}$ & 38.23 & 82.03 & 83.40 & 110.56 & 94.93 & 187 & 103.36 & 112.06 & 33.47 & 37.19 & 58.29 & 60.13 \\
\hline & $3^{\text {rd }}$ & 0 & 41.53 & 0 & 61.40 & 0 & 89.66 & 0 & 42.70 & 36.49 & 39.10 & 58.57 & 57 \\
\hline & $4^{\text {th }}$ & 0 & 0 & 0 & 0 & 0 & 0 & 0 & 0 & 33.47 & 37.23 & 57 & 56.20 \\
\hline \multicolumn{2}{|c|}{ Total } & 1176.50 & 1584.74 & 1446.30 & 1459.44 & 1597.98 & 1679.91 & 1923.56 & 1742.43 & & & & \\
\hline
\end{tabular}


The correlation was insignificant for maximum relative humidity during the same seasons for the four districts, while there were highly significant positive correlation with minimum relative humidity during the second season $(r=0.957)$ in AbouHammad , while there were significant positive correlation with minimum relative humidity in second seasons in Belbeis and Meniet El-Kamh where $r=0.740$ and 0.804 , respectively.

Table 6. Correlation between temperature, relative humidity and population densities of Aphis

\begin{tabular}{|c|c|c|c|c|c|c|c|c|c|}
\hline \multirow{3}{*}{ Variables } & Crop & \multicolumn{8}{|c|}{ Maize } \\
\hline & Seasons & \multicolumn{4}{|c|}{2008} & \multicolumn{4}{|c|}{2009} \\
\hline & Localities & Zagazig & Belbeis & $\begin{array}{l}\text { Abou- } \\
\text { Hammad }\end{array}$ & $\begin{array}{l}\text { Meniet } \\
\text { El-Kamh }\end{array}$ & Zagazig & Belbeis & $\begin{array}{l}\text { Abou- } \\
\text { Hamma } \\
\text { d }\end{array}$ & $\begin{array}{c}\text { Meniet } \\
\text { El- } \\
\text { Kamh } \\
\end{array}$ \\
\hline \multicolumn{2}{|c|}{ Tem $\max$} & -0.262 & -0.488 & 0.045 & 0.060 & -0.421 & -0.438 & -0.073 & 0.169 \\
\hline \multicolumn{2}{|c|}{ Tem min } & 0.171 & 0.080 & -0.018 & -0.017 & 0.021 & 0.400 & -0.183 & -0.113 \\
\hline \multicolumn{2}{|c|}{ R.H. max } & -0.417 & -0.536 & 0.383 & 0.358 & -0.389 & -0.496 & 0.553 & 0.430 \\
\hline \multicolumn{2}{|c|}{ R.H. min } & 0.537 & 0.702 & $0.814 *$ & $0.788^{*}$ & 0.659 & $0.740 *$ & $0.957 * *$ & $0.804 *$ \\
\hline
\end{tabular}



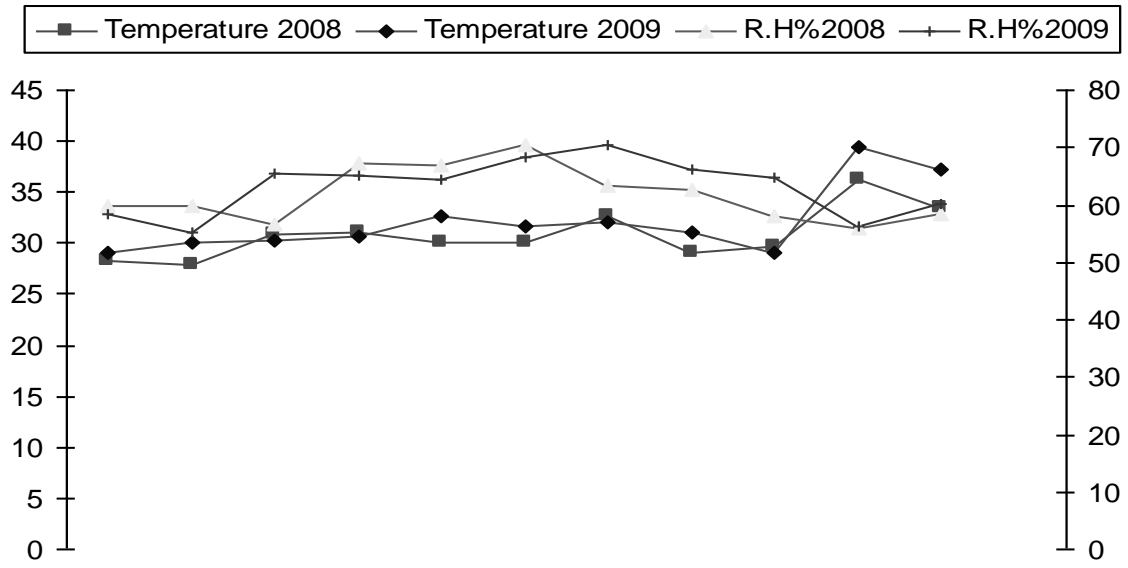

2008

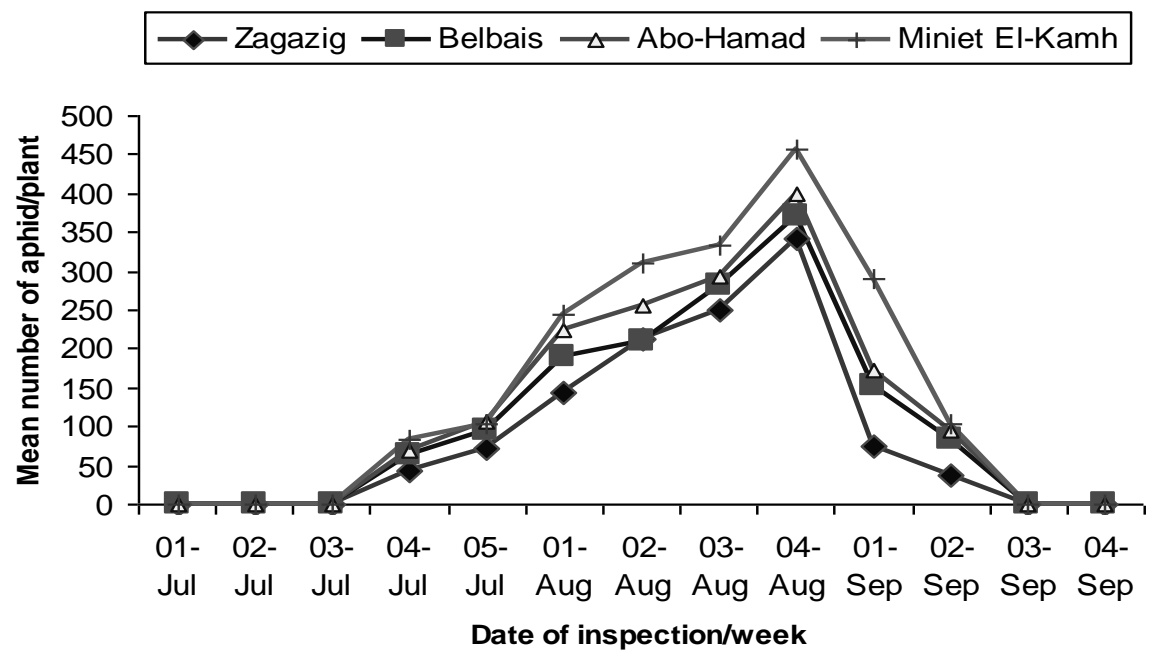

2009

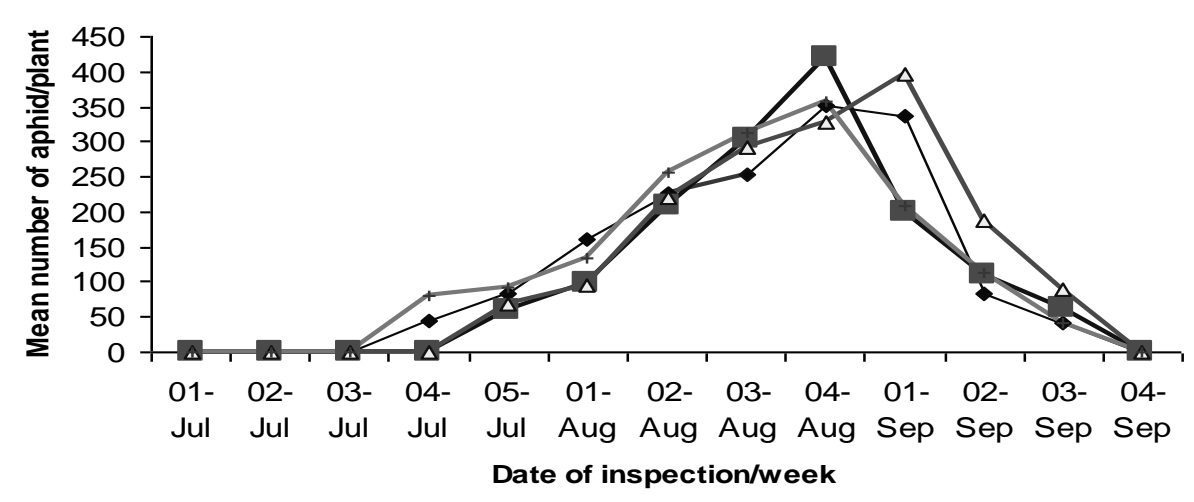

Fig 3. Population fluctuation of Aphis gossypii (G.) infesting maize plants collected by plant samples at 4 districts, Sharkia Governorate during 2008 and 2009 season. 


\section{REFERENCES}

1. Abd Alla-Zeinab, M. 1984. Studies on aphids in Sharkia region. Ph. D. Thesis, Fac. Agric., Zagazig Univ.

2. Abd-Allah, K. A. 1985. Studies on Rhopalosiphum maidis at Zagazig region. M. Sc. Thesis, Fac. Agric., Zagazig Univ.

3. Amal, Z. N. E. Al-Habashy. 2008. Studies on certain insects pests infesting some Graminaceous field crops. Ph. D. Thesis, Fac. agric. Moshtohor, Banha Univ.

4. El-Heneidy, A. H., G. N. Rezk, M. I. Abdel-Megeed and S. S. M. Samad. 2004. Comparative study of cereal aphids species and their associated predators and parasitoids in two different wheat regions in Egypt. Egypt. J. of Biologic. Pest. Control, 14(1):217-224.

5. Farag, E. I., M. K. Rai and V. K. Sharma. 1992. Relative susceptibility of some maize varieties to aphid, Rhopalosiphum maidis. J. of Plant Pathology, 103(6):515-519.

6. Ganguli, A. M., R. W. Ray chaudry. 1985. Survey and seasonal abundance of leafhoppers infesting certain solanaceous vegetable plants in newly reclaimed sandy areas in France, Laboratiore density Zoologie Domaine density La Mottle, 297-303.

7. Hegab-Ola, I. M. S. 2001. Studies on certain insect vectors of plant Pathogenic agents. Ph. D. of Sci. Fac. Agric., Zagazig Univ.

8. Hegab, A. M. 1987. Studies on certain pests infesting vegetables in Egypt .M. Sc. Thesis, Fac. Agric., Zagazig Univ.

9. Mohamed, I. A. 1996. Influence of cereal aphids infestation on wheat varieties under constant laboratory conditions Egyptian J. of Agric. Res., 78(1):163172.

10. Snedecor, G. W. and W. G. Cochran. 1982. Statistical Methods 7th Edition. Iowa State Univ. press U. S. A: 365-372pp. 


\section{تذبذب تعداد بعض حشرات المن التى تصيب الذره الثامية فى محافظه الثرقية}

\section{السيد على حسن شريف2 , فارس أمين محمد اللقوه1, أحمد عبدالغفار درويش1 \\ ,}

$$
\begin{aligned}
& \text { 1. قسم وقايه النبات ـ كليه الزراعه بشتتهر - جامعه بنها } \\
& \text { 2. مركز البحوث الزراعبه - معهر بحوث وقايه النباتات ـ الدقى - الجبزة }
\end{aligned}
$$

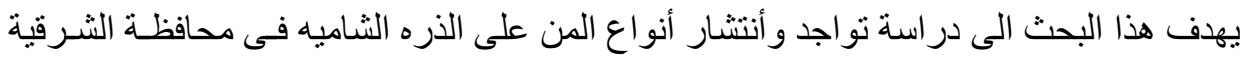

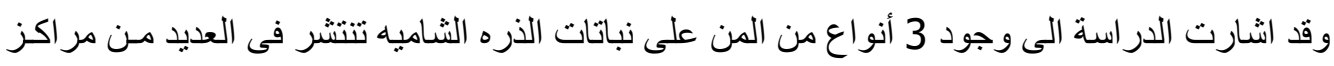

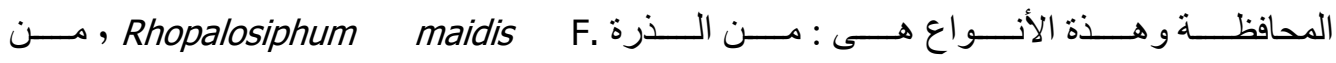

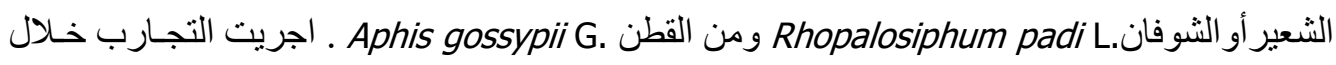

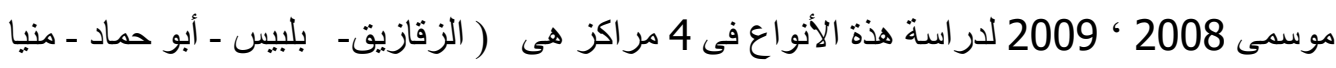

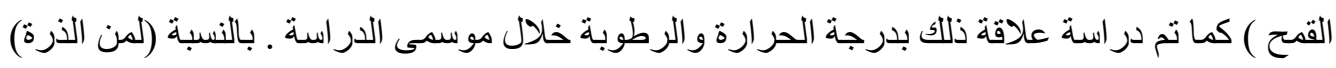

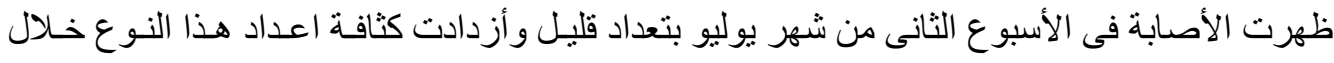

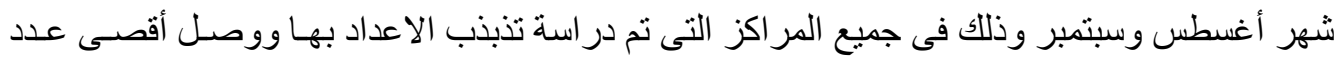

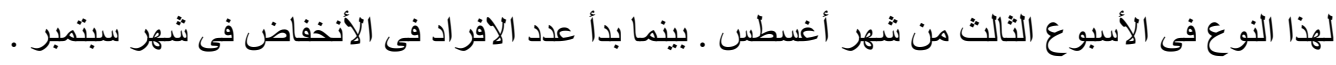

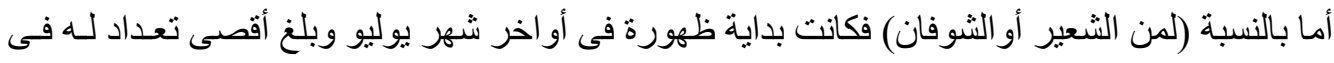

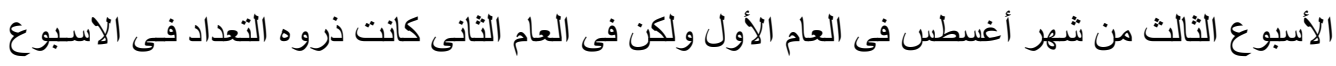

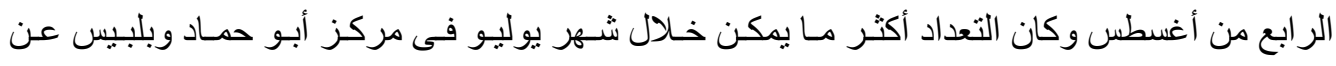

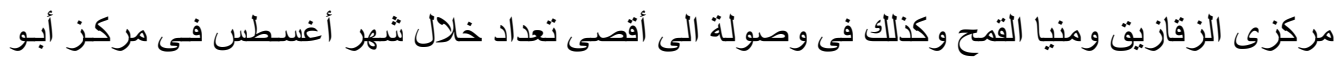

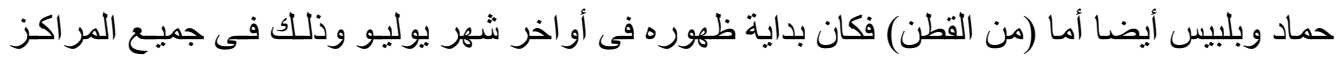

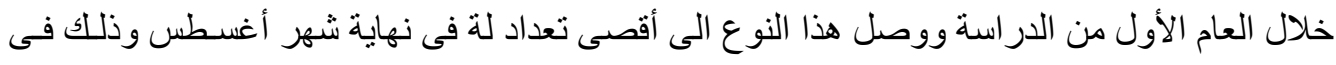

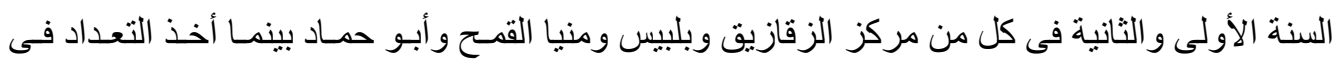

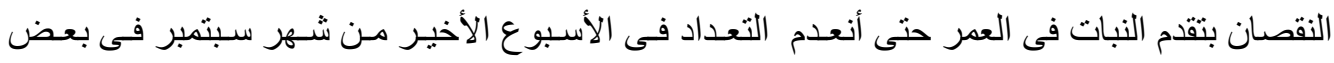

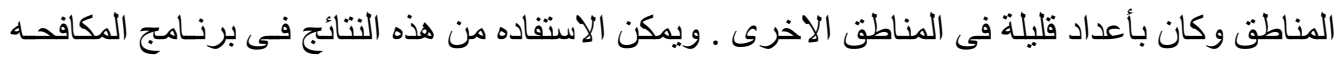

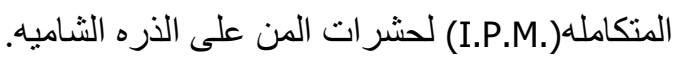

